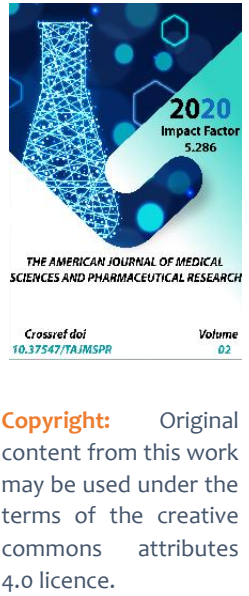

\title{
Method For Determining The Content Of Toxic Substances In The Liver After Exposure To Pesticides In Experimental Animals
}

\author{
Mamasaidov Jamolidin Turginbaevich \\ Candidate Of Medical Sciences, Associate Professor Of The Department Of General Surgery \\ Fergana Medical Institute Of Public Health, Uzbekistan
}

\section{ABSTRACT}

This scientific work is devoted to the study of the results of the action of pesticides on the organism of experimental animals. At the beginning, a brief review of the literature devoted to this problem is given. The author also describes a method for determining the content of toxic substances in the liver tissues of experimental animals. The corresponding conclusions on the simplicity of the method are made.

\section{KEYWORDS}

Liver, experimental animals, pesticides, toxic substances, method of determination;

\section{INTRODUCTION}

Pesticides and herbicides are often used in agriculture to kill pests and weeds and increase production. They are also used to prevent the spread of insect diseases such as mosquitoes, flies and termites.
The modern use of pesticides has been recognized as indispensable for improving agricultural production. At the same time, pesticides have been recognized as environmental pollutants causing toxicological danger to animals, as evidenced by their acute 
chronic toxic [6]. Pesticides are highly toxic to most animals. Synthetic pyrethrin analogs, cineraiaefolium ornamental chrysanthemum extracts, have been developed to circumvent the problem of rapid photodegradation faced by insecticidal natural pyrethrins.

However, exposure to pesticides can cause histological changes in the liver, and therefore histological examination of exposed specimens can provide meaningful results. In the liver, pyrethroids undergo oxidation and hydrolysis to form glucuronates. The high rate of oxidation and elimination of these substances from the body is due to the presence of easily degradable structures in their molecule.

The research of the effect of pesticides on rat liver cells was carried out by Mariana Astiz, Maria J. T. de Alanis, Carlos Alberto Marra. The goal of their work was to find out if oxidative stress caused by pesticides can affect the survival of liver cells.

\section{MATERIAL AND RESEARCH METHODS}

Pesticide treatment of Wistar rats (ip 1/250 LD50, three times a week for 5 weeks) caused a loss of mitochondrial transmembrane potential and cardiolipin content, especially in the substantia nigra (SN), with a concomitant increase in fatty acid peroxidation. The activation of the apoptosacalpain cascade (instead of the caspase-dependent pathway) may be responsible for the observed pattern of DNA fragmentation. Methods for the determination of pesticides: biological determination of poisoning with pesticides (determination of organochlorine compounds, determination of organophosphorus compounds, derivatives of carbonic acid, chlorinated salicyanilides, derivatives of carboxylic acids).

The stock solutions used for dosing the rats were prepared by the IANZ-accredited Landcare Research Toxicology Laboratory. All liver tissues were analyzed for anticoagulant concentration at the Landcare Research Toxicology Laboratory, Lincoln. The analyzes for brodifacoum (TLMoog: determination of brodifacum in liver tissue by HPLC) and warfarin (TLM057: determination of warfarin in liver tissue by HPLC) were based on the methods of Hunter (1983). Liver samples were crushed and mixed with anhydrous sodium sulfate and an extraction solvent (chloroform / acetone). The mixture was homogenized with a tissue dispersant, shaken and centrifuged. The supernatant was decanted and the extraction was repeated twice more. The combined extracts were evaporated and placed in hexane / chloroform / acetone for loading on a gel permeation column for purification. The eluent from the column was again evaporated and collected in the mobile phase for HPLC determination, which used post-column $\mathrm{pH}$ switching and fluorescence detection.

It was found that to compare the toxicity of vertebrate pesticides for different species, it is common practice to use indices such as acute LD values; variability in the susceptibility of different rodent species (and between the sexes of the same species) to anticoagulant compounds was noted (Ashton et al., 1987).Differences in the kinetics of anticoagulant clearance in different rodent pests such as Rattusrattus and P. norvegicus in the field should also be taken into account in 
the future, as this may contribute to different risks of residue formation and secondary poisoning depending on the species of target rodent [7].

\section{Determination of methylnitrophos in rat liver by gas-liquid chromatography.}

The mechanism of action of organophosphorus compounds, and fenitrothion in particular, is due to the phosphorylating and alkylating properties of these compounds. Entering the body, fenitrothion phosphorylates the vital enzymes acetyl cholinesterase, aliesterase and others.

The toxicity of the substance to warm-blooded animals, insects, and ticks is due to the phosphorylation of acetyl cholinesterase (AChE), which plays an extremely important role in the transmission of nervous excitement. Through the neuron, nervous excitement is transmitted in the form of a kind of electrical signal, and through the synaptic cleft - with the participation of chemical mediators, one of which is acetylcholine (ACh).

By phosphorylating $\mathrm{AChE}$ and thus turning it off for a long time from its usual sphere of action, fenitrothion, like other organophosphate insecticides, disrupts the complex biochemical cycle of acetylcholine metabolism. Its accumulation in the tissues of the nervous system leads to hypertrophied excitability, dysfunction of various organs and, ultimately, to poisoning of the body.

A sample of organs or tissues (20 g) is crushed and placed in a flask with a ground stopper, extracted three times with diethyl ether in portions of 30,10 and $10 \mathrm{ml}$ for 60,10 and 10 minutes in the cold with periodic shaking. The extracts are successively passed through a filter with anhydrous sodium sulfate into a Petri dish and evaporated to dryness in a fume hood. The residue is dissolved in $0.8 \mathrm{ml}$ of chilled acetone and filtered through an ashless filter into a $10 \mathrm{ml}$ flask; the Petri dish is washed 3-4 times with acetone, which is filtered through the same filter.

The acetone solution is left in the refrigerator for 12-14 hours, while the fat settles, and the acetone layer on top contains the pesticide. Carefully suck off the entire acetone solution with a syringe and apply it to a chromatographic plate (sorbent - aluminum oxide). In parallel with the investigated toxic chemical, "witnesses" are applied - 10 and 30 mkg of a standard MNF acetone solution. Mobile solvent: hexane chloroform (1:1). When the solvent has risen $10 \mathrm{~cm}$ from the starting line, remove the plate and dry. Then the plate is sprayed with $20 \% \mathrm{NaOH}$ solution and heated in an oven at $180^{\circ}$ for 10 minutes. If methylnitrophos is present in the test material, lemon-yellow spots are formed with 0.53-0.57.

Quantification is carried out by measuring the areas of the spots of the sample and the standard and visually comparing the intensity of their color. The content of methylnitrophos (in $\mathrm{mg} / \mathrm{kg}$ ) is calculated by the formula:

$$
\mathrm{X}=\frac{S * \mathrm{C} * m}{S_{\mathrm{cT}} * C_{\mathrm{cT}}}, \text { where }
$$

where $S$ is the spot area of the test sample $(\mathrm{mm})$; Sst - spot area of the standard; Cst is the amount of methylnitrophos in the standard (mg/kg); m - sample portion. 
The method allows you to determine 5-10 mkg and more in the sample. The accuracy of the method is $85 \%$.

In mammals, a large percentage of pesticides are found in the kidneys, liver, spleen, and intestines.

\section{Method for the determination of pesticides by chromatographic method}

The technical problem is solved by the fact that the method for determining pesticides in a biological material using HPLC includes sampling, extraction with an organic solvent, evaporation, dissolving the dry residue and introducing it into the chromatograph, processing the analysis results, taking a sample of the animal's liver as a sample, homogenizing it with anhydrous sodium sulfate and sodium hydroxide, extracted with acetonitrile, shaken and defended, then centrifuged at $3000 \mathrm{rpm}$ and add sorbents - silica gel C18, Bondesil-PSA and anhydrous sodium sulfate, after which centrifugation is repeated, the dry residue is dissolved in acetonitrile, then analyzed using HPLC with UV detector [11].

Example $1.5 \mathrm{~g}$ of rat liver is homogenized in a 50 $\mathrm{dm} 3$ test tube with $10 \mathrm{~g}$ of anhydrous sodium sulfate and $0.6 \mathrm{~g}$ of sodium hydrocitrate. Then add $8 \mathrm{dm}^{3}$ acetonitrile and, after vigorous shaking for 1 minute, settle for 30 minutes.

After that, the mixture was centrifuged for 5 minutes at $3000 \mathrm{rp} / \mathrm{m}$, the acetonitrile layer was poured into a $15 \mathrm{dm}^{3}$ test tube and $50 \mathrm{mg}$ of Bondesil-PSA sorbent (enterosorbent SUMS-1), $50 \mathrm{~g}$ of $\mathrm{C} 18$ sorbent and $1.2 \mathrm{~g}$ of anhydrous sodium sulfate were added, shake vigorously 1 minute and stand for 30 minutes.
Then the mixture was centrifuged again for 5 minutes at $3000 \mathrm{rp} / \mathrm{m}$, the acetonitrile layer was poured into a $100 \mathrm{ml}$ flask and concentrated to a volume of $1 \mathrm{ml}$ on a vacuum concentrator at $38-40^{\circ} \mathrm{C}$.

Dissolve the solvent and dry residue in $1 \mathrm{~cm}^{3}$ of acetonitrile and analyze on a liquid chromatography with an ultraviolet detector equipped with a degasser and a column thermostat. Column $4.6 \times 150 \mathrm{~mm}$; working wavelength - $230 \mathrm{~nm}$, temperature control - + $40^{\circ} \mathrm{C}$; mobile phase: acetonitrile - $0.005 \mathrm{M}$ orthophosphoric acid in a ratio of 60:40 (by volume) in isocratic mode; the flow rate is 0.6 $\mathrm{ml} / \mathrm{min}$, the volume of the sample extract introduced into the chromatograph is $10 \mathrm{mkl}$. Identify pesticides by retention time.

Determine the quantitative content based on the area of the chromatographic peak using the equation of the calibration graph.

Take an aqueous solution of pesticides as a control sample.

\section{CONCLUSION}

The proposed methods are designed for the determination of pesticides in animal cells and, in comparison with prototypes, is simpler, more economical and effective, because allows you to determine 10-13 pesticides in one sample instead of one.

\section{REFERENCES}

1. Ataman alp. M.. (2000). Bir Sentetik Piretroitin sektisitinin Subletal Dozlannin 
Gokkußagi

Alabaligi

(OncorhynchusmykissW..1792)'na

Makroskobik. Histopatolojik.

Hematolojikve Biyokimyasal Etkileri.

DoktoraTezi. Ataturk Universitesi Fen Bilimleri Enstitusu. Erzurum.

2. Astiz M, de Alaniz MJ, Marra CA. Effect of pesticides on cell survival in liver and brain rat tissues. Ecotoxicol Environ Saf. 2009 Oct;72(7):2025-32. doi: 10.1016/j.ecoenv.2009.05.001. Epub 2009 Jun 2. PMID: 19493570.

3. Begum. G..Vijayaraghavan. S.. (1995). In Vivo Toxicity of Dimethoate on Proteins and Transaminases in the Liver Tissue of Fresh Water Fish Clariasbatrachus (Linn). Bull. Environ. Contam. Toxicol. 54:370-375.

4. Bradbury, S.P., Coats, J.R., (1989). Comparative toxicology of the pyrethroid insecticides. Rev. Environ. Contamin. Toxicol, 108: 133-177.

5. Mariana Astiz, María J T De Alaniz, Carlos Alberto Marra. Effect of pesticides on cell survival in liver and brain rat tissues. Ecotoxicology And Environmental Safety. DOI: 10.1016/j.ecoenv.2009.05.001.2009.

6. VanDyk JC., Pieterse GM., van Vuren JHJ., (2007) Histological changes in the liver of Oreochromismossambicus (Cichlidae) after exposure to cadmium and zinc. Ecotoxicology and Environmental Safety 66: 432-440.

7. Fisher, Penny \& O'Connor, C. \& Wright, G. \& Eason, Charles. (2003). Persistence of four anticoagulant rodenticides in the livers of laboratory rats.

8. Nelson, PC; Hickling, GJ 1994: Pindon for Rabbit Control: Efficiency, Residue, and Cost. P. 217-222 in Halverson, Washington;
Crabb, AC (ed.): Proceedings of the 16th Vertebrate Pest Conference. University of California at Davis, Davis, California, USA.

9. O'Brien, PH; Beck, JA; Lukins, B.S. 1987: Residual tissue levels of warfarin and 1080 in poisoned feral pigs. Working paper presented at the Australian Vertebrate Pest Control Conference (unpublished). 6 pcs.

10. Parmar, G .; Bratt, H .; Moore, R .; Batten, $P L$ 1987: Evidence for a common in vivo binding site for anticoagulant retention in rat liver. Human Toxicology 6: 431-432.

11. Zinchuk O.A. Method for determination of pesticides in biological material using HPLC. 